\title{
XENOPHON'S SOCRATES ON WISDOM AND ACTION
}

\begin{abstract}
Xenophon's Socrates, like Plato's, holds that wisdom comes with practical abilities. But influential interpretations of Xenophon's Socrates attribute to him a splintered view of wisdom, on which there is no wisdom simpliciter which is specially connected to all good actions. This article argues that a crucial text (Memorabilia 3.9.5) is significantly more problematic for the splintered view than hitherto appreciated, while the texts which are supposed to support the splintered view do not. Instead, this article argues that for Xenophon's Socrates the unwise lack self-knowledge, and so also lack a special prohairetic ability needed for doing fine and good actions.
\end{abstract}

Keywords: Xenophon; Socrates; wisdom; self-knowledge; Memorabilia; Socratic moral psychology

Xenophon's Socrates, like Plato's, thinks that wisdom comes with some practical abilities. In one way, the textual evidence for this is straightforward. In Memorabilia (=Mem.) 3.9.5, he says that 'the wise will do the fine and good, and the not wise will not be able to and, even if they try, they will go wrong.' But interpreting that remark is not so straightforward. According to recent interpretations put forward by Dorion and by Morrison, ${ }^{1}$ Xenophon's Socrates has a 'splintered' view of wisdom, on which there are multiple non-identical kinds of wisdom at issue in that passage, rather than wisdom simpliciter, and each distinct kind of wisdom is connected to a different kind of successful action (Dorion [n. 1 (2012)], 466):

sophia is nothing more, it seems, than a specific ability in a given area, whatever one that may be. In other words, sophia is a specific knowledge in a limited field of endeavour, which could derive just as well from varying technical expertise as from morality.... The sophia in which justice consists, namely, knowledge of the laws (cf. 4.6.6), is thus distinct from the individual sophiai in which piety (4.6.2-4) or courage (4.6.10-11) or any other virtue consist.

The splintered view, if correct, would provide a much-needed explanation of why Socrates thinks that wisdom comes with practical abilities. In effect, it indexes wisdom to those practical abilities: those who are especially skilled when it comes to carpentry will be carpentry-wise, while those who are especially knowledgeable when it comes to the lawful will be justice-wise. That is just what it is to be wise in those ways and, because there is no wisdom simpliciter, there is no way to be wise, without being wise in some such specific way, or about some specific domain of actions.

\footnotetext{
${ }^{1}$ L.A. Dorion, 'La nature et le statut de la sophia dans les Mémorables', Elenchos 29 (2008), 253-77; id., 'The nature and status of sophia in the Memorabilia', in F. Hobden and C. Tuplin (edd.), Xenophon: Ethical Principles and Historical Enquiry (Leiden, 2012), 455-76; D. Morrison, 'Xenophon's Socrates on sophia and the virtues', in L. Rossetti and A. Stavru (edd.), Socratica 2008. Studies in Ancient Socratic Literature (Bari, 2010), 227-39.
} 
But in this paper I argue that Xenophon's Socrates does not have a splintered view of wisdom-although he does have an interesting and neglected account of why wisdom comes with practical abilities. In the first section, I argue that the argument of Mem. 3.9.5 (in which the claim quoted above appears) favours a unified view of wisdom over the splintered view. In the second section, I argue that four passages put forward in support of the splintered view do not support it. So Xenophon's Socrates can agree with Plato's that wisdom is unified rather than splintered. But in the third section, I sketch an account of why Xenophon's Socrates thinks that only the wise will be able to do the fine and good. On that account, Xenophon's Socrates differs significantly from Plato's in explaining the practical abilities of the wise in terms of a further prohairetic ability to choose the fine and good.

\section{WISDOM AND VIRTUE IN MEM. 3.9.5}

As I read Mem. 3.9.5, it says:

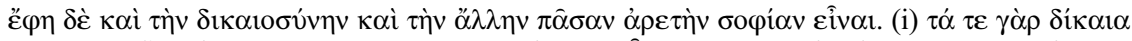

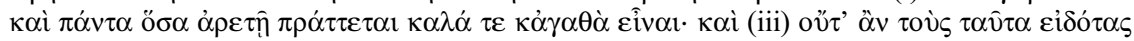

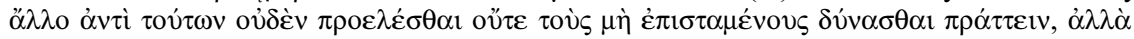

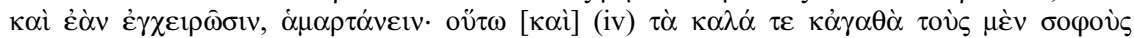

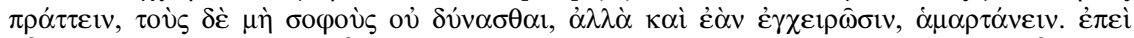

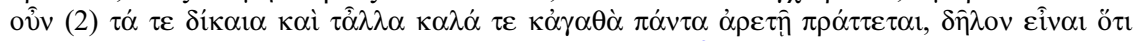

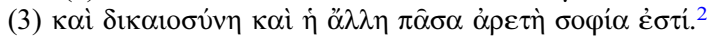

He [Socrates] said that both justice and every other virtue were wisdom. For (i) just things and whatever is done by virtue are fine and good. And (iii) neither will knowers of these things choose anything instead of them, nor would those who don't know [them] be able to do them, but, even if they try, they will go wrong. So too (iv) the wise will do the fine and good, and the not wise will not be able to and, even if they try, they will go wrong. So, since (2) just things and all other fine and good things are done by virtue, it is clear that (3) both justice and every other virtue is wisdom.

The text of the passage is clearly corrupt in one crucial place in (iii), where the manuscripts read "nor would those who know [them] not be able to do them, but, even if they try, they will go wrong'. Since I can see no way to make good sense of the passage on that reading, I accept Victorius's emendation of the manuscript reading

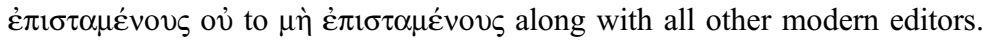

However, I reject another emendation which Dorion accepts. Rather than (2) reading 'just things are done by virtue' with the manuscripts, Dorion accepts an emendation on which (2) reads 'just things are done by wisdom', on the grounds that it is necessary to make sense of the argument. By giving a reasonable version of the argument below using the manuscript reading, I show that this emendation is unnecessary. That is, in turn, a strong reason to prefer the reconstruction below. ${ }^{3}$

\footnotetext{
${ }^{2}$ The numbers inserted into the text indicate the sources of the premises in the arguments reconstructed below.

${ }^{3}$ In fact, a failure to appreciate the careful articulation of the argument goes a long way to explaining earlier readings. So, for instance, Dorion takes (2) to be tautological, rather than precisely that causal claim which is needed to license the conclusion, in conjunction with (1) and the heuristic below (L.A. Dorion and M. Bandini, Xénophon Mémorables, Tome II, $1^{\text {re }}$ Partie, Livres II-III [Paris, 2011], 350-1 n. 11). Dorion also needlessly takes (2) to be an interim conclusion, rather than taking
} 
The basic structure of the argument, as I understand it, is quite simple. Socrates argues that wisdom causes the same actions as justice and the other virtues, and then concludes that the causes of these actions are the same. That is:

(1) Wisdom causes all and only virtuous actions

(2) Virtue causes all and only virtuous actions

hence (3) Virtue = Wisdom ((1), (2), (heuristic)).

This argument relies on an unstated but plausible heuristic such as:

(heuristic) if $\mathrm{x}$ and $\mathrm{y}$ cause the same actions, then $\mathrm{x}=\mathrm{y}$.

If Socrates ${ }^{4}$ is not supposing something like this heuristic, it is hard to see how the argument could go. ${ }^{5}$ What else would license a move from the claims Socrates starts with, about what the wise and just do, to his conclusion that the causes of those actions-that is, justice and wisdom (or justice-wisdom, on the splintered view) - are the same? ${ }^{6}$

On this understanding of the argument, the bulk of $\S 5$ is devoted to arguing for (1) the claim that wisdom causes all and only virtuous actions-as follows:

(i) Virtuous actions = fine and good actions (premise)

hence (ii) Any cause of fine and good actions is also a cause of virtuous actions (from (i))

(iii) Knowledge of the fine and good causes all and only fine and good actions (premise)

hence (iv) Wisdom causes all and only fine and good actions (from (iii), that wisdom $=$ knowledge of fine and good)

hence (1) Wisdom causes all and only virtuous actions (from (ii), (iv)).

This straightforward reading of the argument favours a unified view of wisdom over the splintered view, for two reasons. First, the move from the claim about knowledge of the fine and good in (iii) to the claim about wisdom in (iv) requires that wisdom be identical to the knowledge of the fine and good. That is exactly the kind of wisdom simpliciter which the splintered view, at least in Dorion's version, denies that we find in Xenophon. Second, the argument depends on there being one class of actions which is caused both by wisdom and by virtue: it is the identification of those classes which licenses the conclusion that the apparently different causes are in fact identical. So there will not be distinct classes of actions caused by distinct kinds of wisdom, as the splintered view would have it. It is not courage-wisdom which causes courageous

$\dot{\varepsilon} \pi \varepsilon \dot{~ o u ̂ v ~ t o ~ b e ~ i n t r o d u c i n g ~(2) ~ a s ~ t h e ~ a d d i t i o n a l ~ p r e m i s e . ~ F o r ~ r e c e n t ~ a n d ~ r e l a t e d ~ c r i t i c i s m ~ o f ~ D o r i o n ' s ~}$ reading, see R.E. Jones and R. Sharma, 'Virtue and self-interest in Xenophon's Memorabilia 3.9.4-5', CQ 68 (2018), 79-90, at 87, especially nn. 30-1.

4 By 'Socrates' here and in the rest of this paper I mean Xenophon's Socrates, unless otherwise specified.

${ }_{5}$ Other principles might underwrite the move to (3) - for instance, the principle that each action has only one cause. But (heuristic) seems more plausible: after all, many psychological behaviourists and functionalists would have believed it.

${ }^{6}$ Dorion's reconstruction of the argument faces the same difficulty, but does not acknowledge it, and so does not meet it. From the fact that actions A (i.e. good ones) are done by wisdom, and the fact that all actions of type B (i.e. just actions) are also of type A, it does not follow that there is such a thing as justice, nor that, if there were, wisdom would be identical to it-contra Dorion's reconstruction ([n. 3], 351 n. 11). 
actions, a distinct justice-wisdom which causes just actions, and a distinct piety-wisdom which causes pious actions. ${ }^{7}$ Instead, it is wisdom simpliciter which causes virtuous actions as a whole.

Defenders of the splintered view may instead want to read the argument schematically, so that, instead of one determinate argument about virtue, the passage contains an argument schema with justice as a placeholder. If we replace justice with piety, however, we get a different argument: one about piety. The resulting arguments would be about distinct classes of actions, as the splintered view would predict. There would be one argument which concluded that justice-wisdom was identical to justice, because both cause just actions, while another argument concluded that piety-wisdom was identical to piety, because both cause pious actions, and so on.

Though this schematic reading is possible, it is not a good fit for the text. For one thing, although the argument does make specific mention of justice, it is explicitly aimed not at each of the virtues but at the whole rest of virtue ( $\dot{\eta} \ddot{\alpha} \lambda \lambda \eta \pi \hat{\alpha} \sigma \alpha \dot{\alpha} \rho \varepsilon \tau \dot{\eta})$. That formulation strongly suggests that justice is here viewed as part of a wholethat is, virtue-rather than as a placeholder for any individuals of the same speciesthat is, virtues. ${ }^{8}$ The present reading lets us take that suggestion seriously: it is not virtues which are identified with wisdoms, as on the schematic reading, but virtue as a whole which is identified with wisdom simpliciter. Moreover, (iii) does not invite a schematic reading: there is no suggestion that the fine and good are to be filled out with 'just actions that are good' in one argument, but with 'pious actions that are good' in another version. ${ }^{9}$ There is no reason to read (iii) as having the blanks which a schematic reading asks us to find.

For these reasons, the present argument is quite different from other plausibly schematic claims about wisdom or virtue. For instance, when Plato's Socrates says at Euthyd. 280a6 that wisdom makes humans fortunate, he plausibly means that medical wisdom makes one fortunate when it comes to medicine, strategic wisdom makes one fortunate when it comes to campaigning, and so forth. ${ }^{10}$ But what makes a schematic reading of that claim plausible is that it is preceded by specific and explicitly distinguished species of wisdom which serve as inductive support for a conclusion about a genus. Each of a number of distinct kinds of wisdom are fortunate, so (the argument goes) wisdom is fortunate. By contrast, in the present argument, there is no reason to suppose that there are distinct kinds of virtue at issue, and some reason to suppose that there are not.

\footnotetext{
7 Though Dorion and Morrison understand the relation between sôphrosynê and wisdom differently, they agree on that justice, piety and courage are distinct in these ways: Dorion (n. 1 [2012]), 466-7; Morrison (n. 1), 238.

${ }^{8}$ Compare the parallel formulation at Xen. Hell. 6.4.12, where the Thebans attempt to overcome one part of the Lacedaemonian army, reasoning that it would then be easy to overcome the rest ( $\tau$ ò $\left.\ddot{\alpha} \lambda \lambda_{0} \pi \hat{\alpha} v\right)$. Clearly the thought there is not that it would then be easy for the Thebans to overcome each individual soldier - that would have been true in any case-but that it would then be easy to overcome the whole of the remaining army.

9 There is a way to read the text of premise (iii) more schematically, namely, to take the antecedent

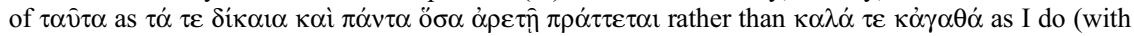
Jones and Sharma [n. 3], 87 n. 31, and against both Dorion [n. 3], 349 n. 9 and A. Delatte, $L a$ troisième livre des Souvenirs Socratiques de Xénophon [Paris, 1933], 121). In favour of the present reading is the tendency of oư $\tau$ s to have proximate antecedents (H.W. Smyth, A Greek Grammar [New York, 1920], 307).

${ }^{10}$ I am grateful to Rusty Jones for pressing on me the importance of this objection.
} 


\section{WISDOM SIMPLICITER IN XENOPHON'S SOCRATICA}

So the splintered view is hard to reconcile with Mem. 3.9.5. But the passages which Dorion and Morrison take to support the splintered view lie elsewhere. If those passages really do commit Socrates to the splintered view of wisdom, there might be sufficient interpretative pressure to force the schematic reading of 3.9.5. Four passages in particular are thought to commit Socrates to the following three theses:

(i) wisdom is morally ambivalent: not always good (or not always good for its possessor)

(ii) there is no cognitive state which might be wisdom simpliciter

(iii) there is no unified cognitive content which might be the content of wisdom simpliciter

These three theses would support the splintered view: (ii) and (iii) by ruling out wisdom simpliciter, and (i) because the splintered view would best explain why wisdom was morally ambivalent. I will take them each in turn, explaining why the relevant passages might be thought to support them, and why they in fact do not.

First, and most strikingly, both Morrison and Dorion take Mem. 4.2.33 to support (i) (Dorion [n. 1 (2012)], 455-8; Morrison [n. 1], 230-1). In that section, Socrates refutes

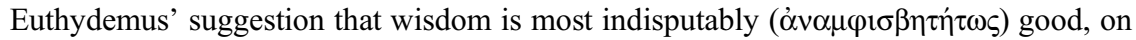
the grounds that Daedalus, Palamedes and others have been harmed because of their wisdom.

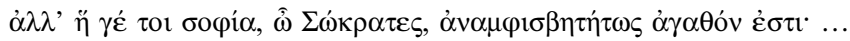

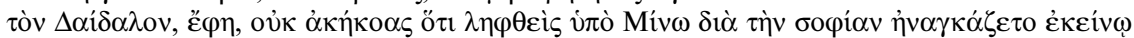

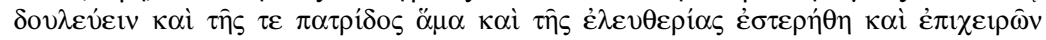

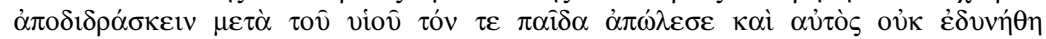

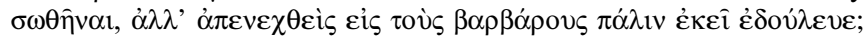

[Euthydemus]: But wisdom, at least, is most indisputably a good ...

[Socrates]: Have you not heard of Daedalus - that he was taken by Minos on account of his wisdom, forced to serve him and deprived of his fatherland and freedom, and trying to escape with his son, lost the boy and was unable to save himself, but being carried off among the barbarians was again a slave? ${ }^{11}$

The splintered view offers a promising diagnosis of why Socrates would give this argument. For, while wisdom in an area is connected to success in that area, all kinds of wisdom are importantly limited, and do not guarantee success outside of their fields. Cobblers are bad carpenters; the just, who know about laws, may be law-abiding but cowardly; Daedalus was a great inventor but not unexceptionable as a parent, and positively hopeless at securing his own freedom. On the splintered view, Socrates gives the argument because he believes that wisdom is in fact morally ambivalent.

But what Socrates goes on to argue next suggests that this promising diagnosis is wrong. For Socrates next refutes Euthydemus' suggestion that happiness is a most indisputable ( $\alpha v \alpha \mu \varphi \imath \lambda o \gamma \omega \dot{\omega} \tau \tau \tau \nu)$ good, on the grounds that none of the other goods of which it could be composed is indisputable.

${ }^{11}$ My translations of 4.2 render the Greek into direct dialogue to make it easier to follow. 


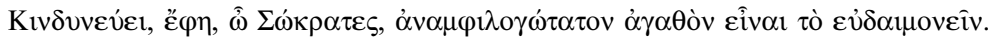

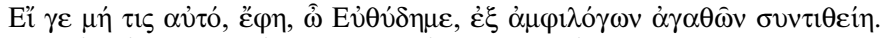

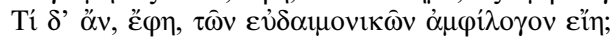

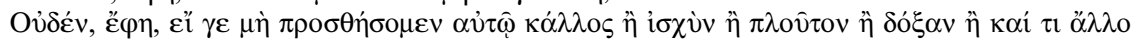

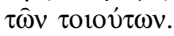

[Euthydemus]: Perhaps happiness is a most indisputable good?

[Socrates]: If someone had not put it together out of disputable goods.

[Euthydemus]: But which of the eudaimonikōn is disputable?

[Socrates]: None, unless we put forward for it beauty or strength or wealth or reputation or something else of that sort.

These two arguments, about wisdom and happiness, should be treated together. If we take the argument about wisdom to commit Socrates to (i), we should take the argument about happiness to commit Socrates to the claim that happiness is morally ambivalent. But it seems clear that Socrates does not think that happiness is morally ambivalent. ${ }^{12}$ So Socrates need not be committed to (i), either.

There is an additional reason not to take Socrates to endorse (i) in this chapter of the Memorabilia. What it is to be a slave in this chapter, both before and after our passage ( $\S 22-3$ and $\S 39)$ is to be ignorant 'of the beautiful and good and just' rather than to be wise. On that account, Daedalus may either be a slave or be wise: but he cannot be both. So Socrates could not consistently point to Daedalus as an example of someone who was both wise and a slave.

If Socrates is not committed to the conclusions of these arguments, why does he give them? Several explanations are prima facie plausible. Perhaps, for instance, Socrates is committed to the conclusions only in so far as they are understood in terms of Euthydemus' incorrect conceptions, as Johnson suggests. ${ }^{13}$ This explanation would liberate Socrates of commitments across the chapter. An explanation specific to these two arguments about wisdom and happiness seems ceteris paribus better, given the emphasis on indisputability which sets these arguments apart from the others in the chapter. The likeliest such explanation is that Socrates gives the arguments in order to demonstrate a special dialectical status which both theses suffer from, namely, the status of both theses as disputable. ${ }^{14}$ As a result of Socrates' arguments, Euthydemus fails to say the same about the same: having said that wisdom and happiness are good, he then admits that they are not, by failing to counter Socrates' arguments to the contrary. So Euthydemus fails to have knowledge, according to the test in $\$ 21-$ just as Socrates wants to show.

The principal passage which is supposed to support (ii) is Mem. 4.6.7, where Socrates argues as follows:

${ }^{12}$ Hence also Dorion: 'Socrate ${ }^{\mathrm{X}}$ semble contester cette représentation traditionelle du bonheur, mais il ne fait guère de doute qu'il y souscrit également' (L.A. Dorion and M. Bandini, Xénophon Mémorables, Tome II, $2^{e}$ Partie, Livre IV [Paris, 2011], 104).

${ }^{13}$ D.M. Johnson, 'Xenophon at his most Socratic (Memorabilia 4.2)', OSAPh 29 (2005), 39-73, at 68 , focussing on $\S 33$ : 'The problem with the argument Xenophon has Socrates advance here is that the sort of wisdom involved in the examples is not the moral knowledge which Socrates aims for, but rather some technical skill.' Cf. Dorion (n. 1 [2012]) on the 'aporetic' reading of 4.2.

${ }^{14}$ Compare Symp. 3.4, where Antisthenes excludes wisdom and courage from being $\dot{\alpha} v \alpha \mu \varphi \imath \lambda \sigma \gamma \omega \tau \alpha \dot{\alpha} \eta$ on the grounds that they sometimes seem to be harmful. On this reading, the contrast is with claims which are in fact indisputable, as perhaps the principle of non-contradiction is. 


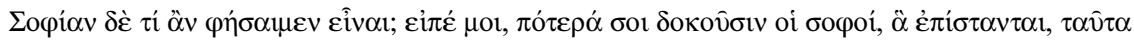

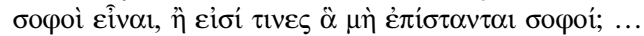

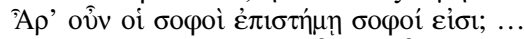

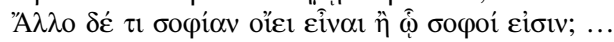

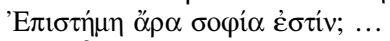

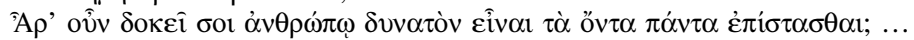

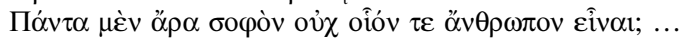

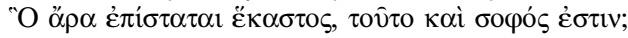

But what shall we say wisdom is? Tell me, do the wise seem to you to be wise in what they know, or are some wise in what they do not know? ...

So the wise are wise by knowledge ...

But do you think wisdom is anything other than that by which they are wise? ...

So wisdom is knowledge. ...

So does it seem to you possible for a man to know all things? ...

And a human can't be wise in all things? ...

What each knows, in this he is also wise?

The idea is that, in this passage, Socrates defines wisdom as knowledge, and takes that definition to entail that wisdom is importantly relative. Just as knowledge is always knowledge of something, so too wisdom is always wisdom of something or in relation to something. Assuming that wisdom simpliciter would then be wisdom of everything, we are supposed to see Socrates' subsequent claim, that no one knows everything, as ruling out wisdom simpliciter. ${ }^{15}$

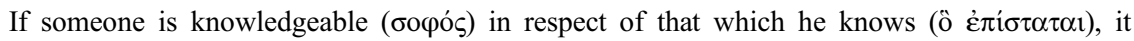
follows that there will be as many distinct sophiai as there are individual areas of knowledge. These sophiai will, for the most part, be technical sophiai situated on an equal footing, without any possibility of identifying one sophia dealing with what is good and bad which would thus have a foundational position with regard to the other sophiai. (Dorion [n. 1 (2012)], 460)

Now, both Plato and Aristotle can agree with the claim that wisdom is knowledge, ${ }^{16}$ and so relative to something-namely, the object of that knowledge. So, if Xenophon's Socrates is in this passage disagreeing with Plato and Aristotle about wisdom simpliciter, as Dorion thinks, that must be because Socrates is assuming that wisdom simpliciter would be wisdom of everything.

It is worth reflecting on why Aristotle in particular does not make that assumption. Aristotle is quite explicit that what it is to be $\mathrm{X}$ simpliciter is often to be $\mathrm{X}$ with respect not to everything but to a special something. For instance, Aristotle thinks both that healthiness is relative and that nothing is healthy for everyone. But he does not take that to mean that nothing is healthy simpliciter. Rather, he thinks that those things are healthy simpliciter which are healthy for a body in good condition (see, for instance, Top. 6.4 142a9-11). In the same way, he thinks that wisdom (sophia) simpliciter is a certain episteme, and that this episteme will have a certain object. Nor was this assumption common ground for Socratics, even leaving Plato aside - for Aristippus rejects it, as Diogenes Laertius reports:

Someone was priding himself for his wide learning, and Aristippus said: 'Just as people who eat the most are not healthier than those who eat what they should, so the wise are not those who have learned a lot, but what is useful. ${ }^{17}$

15 Morrison (n. 1), 236 does not take this passage to support (ii).

16 As they do, at Tht. 145c-e and Metaph. 1.1-2.

17 Diog. Laert. 2.71, transl. G. Boys-Stones and C. Rowe, The Circle of Socrates (Indianapolis, 2013), 156. 
But suppose that Xenophon's Socrates is unlike Aristotle and Aristippus in this respect; suppose that he does assume that wisdom simpliciter would be knowledge of everything. That would explain the significance of one of the conclusions in $\S 7$. The conclusion that it is not possible for a human to be wise with respect to everything would be a way of making the point that no one can be wise simpliciter. That is how Dorion takes it. But there are other ways of making sense of that conclusion, and better ones, on which Socrates is not making that dubious assumption. For instance, perhaps the point is that all humans will sometimes need divination, as Xenophon's Socrates elsewhere insists. ${ }^{18}$ Or perhaps the point is that even a human who is wise simpliciter will sometimes need to call on humans with other areas of expertise-just as the Statesman in Plato's Statesman will need to call on generals, teachers and rhetors. Both of those are reasonable points about human limitations. But neither of them requires the assumption that wisdom simpliciter would be knowledge of everything. So Socrates is not committed to that assumption; and if he is not committed to that assumption, then he is not committed to (ii). In fact, it would be surprising if the chapter were not neutral on important commitments like (ii), since Xenophon tells us in $\S 1$ that he will only relate enough to clarify a Socratic kind of enquiry ( $\dot{\varepsilon} \pi \imath \sigma \varepsilon \dot{\psi} \psi \varepsilon \omega \varsigma)$.

That leaves the third thesis above, namely, that Xenophon's Socrates thinks that there is no unified content which might be the content of wisdom simpliciter. This thesis is supposed to be supported by two further passages, Mem. 3.8 and 4.6.8, too lengthy to quote in their entirety. The thought is that, in those passages, Socrates puts forward the claims that whatever is good is useful for something, and that nothing is useful for everyone or at all times. Dorion writes:

So there is no Good strictly speaking ... nor can there be a sophia understood as knowledge of the Good. Assuming that all knowledge is knowledge of something, the absence or non-existence of an object necessarily entails the impossibility of the knowledge that would relate to it. ${ }^{19}$

But this cannot be right. For one thing, just as the medical art is a unified enough body of knowledge, despite the fact that there is no medicine which is useful for all patients or at all times, so too one might think that there is a unified knowledge of the good, for all that is said in these passages. So these passages do not show that there is no unified good available to be known. Rather, what we learn from these passages is that knowledge of the fine and good will, according to Socrates, include knowledge of uses. Just as doctors will know what is healthy, for whom and when, so too knowers of the fine and good will know what is good for particular individuals in particular circumstances.

${ }^{18}$ Cf. Mem. 1.1.6-9. Morrison (n. 1), 232-3 formulates a similar point in terms of human wisdom. Dorion (n. 1 [2012]), 468-74 quite correctly complains about the point so formulated, on the grounds

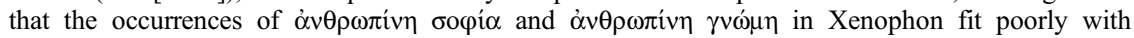
Morrison's characterization of human wisdom. But neither Morrison's formulation nor his specific characterizations at 233 are essential to the point.

19 Dorion (n. 1 [2012]), 460. Morrison (n. 1), 237 follows Dorion in reading the texts, but suggests that the lawful goes 'some way towards explaining how wisdom is possible'. By contrast, I disagree that the texts have the significance Dorion and Morrison take them to have. Aristotle again provides a case in point: phronêsis underwrites a version of the unity of the virtues for Aristotle (in Eth. Nic. $6.12-13)$, despite his claim that 'good' is homonymous. 
Indeed, a major theme of Book 3 of the Memorabilia is that each specific body of knowledge requires more than it is generally taken to require. In chapters 1-2, Socrates claims that generalship requires knowledge of how to make one's underlings happy. In chapter 3 , he argues that cavalry commanders have to persuade their troops to obey them-which, of course, requires knowledge of the fine. In chapter 10, he argues that painters and sculptors need knowledge of the soul. In chapter 11, he arguably aims to show that he, and not his interlocutor the courtesan, is more expert at seduction. So one might sympathize with Glaucon's observation in chapter 6 ( $\S 13-14)$, in response to all the things Socrates tells him he will need to know in order to rule: 'You're talking about an absolutely enormous task, if one ought to concern oneself with such things.' As I understand the two passages presently at issue, the same universalizing tendency is at work in them, rather than a tendency to splinter different bodies of knowledge. Each unified body of knowledge includes more than most people think. Knowledge of goods is no exception.

In short, rather than supporting a splintered view of knowledge of the good, these passages in their context support an encompassing view of knowledge of the good which makes it an excellent candidate to identify with wisdom simpliciter. ${ }^{20}$ That is not to say that Socrates does so identify it. But it is certainly to say that these two passages fail to support (iii), just as the other passages failed to support (i) and (ii).

The upshot is that the texts which are supposed to support the splintered view do not support it, and Mem. 3.9.5 tells against it. But then why does Socrates think that wisdom comes with practical abilities?

\section{WISDOM, CHOICE AND SELF-KNOWLEDGE}

In brief, the account I will sketch is that wisdom simpliciter is self-knowledge, and that self-knowledge is knowledge of one's own ability. So the unwise lack knowledge of their own ability. For that reason, they are unable to choose the fine and good-and because they cannot choose the fine and good, they lack the ability to do the fine and good. Call this the prohairetic account: that (praxis) because (prohairesis) because (dunamis):

(praxis) the unwise are unable to do the fine and good (even if they try)

(prohairesis) the unwise are unable to choose the fine and good

(dunamis) the unwise lack knowledge of their own ability, and so lack self-knowledge.

The pieces of this account are gathered together in Mem. 3.7:

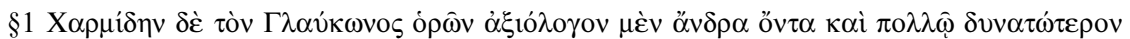

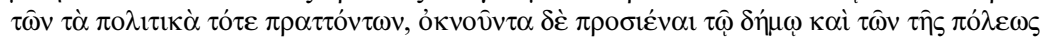
$\pi \rho \alpha \gamma \mu \alpha \dot{\tau} \omega \mathrm{v} \dot{\varepsilon} \pi \mu \varepsilon \lambda \varepsilon \hat{\imath} \sigma \theta \alpha \mathrm{l} . .$.

${ }^{20}$ Even if these passages did present a splintered view of the good, that need not be Socrates' own view. For both passages seem designed to show something about how Socrates does dialectic (cf. Mem. 3.8.1 and 4.6.1). Roughly, the point is that he does not just play with words; he does dialectic, one might say, 'without being soft'. Xenophon can make that point without laying down Socrates' own commitments in 4.6, and without representing Socrates as saying all he has to say about the good in his rather carefully crafted response to Aristippus in 3.8 . 


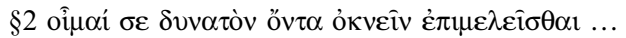

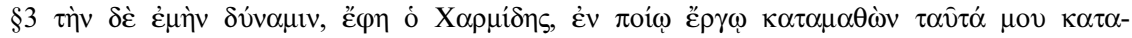
$\gamma \backslash \gamma \nu \omega \dot{\sigma \kappa \varepsilon 1 \zeta ; ~ . . . ~}$

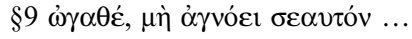

$\S 1$ Seeing that Glaucon's son Charmides was a real mensch and much more capable than the politicians of the day, but shrank from speaking in the assembly and from taking charge of the city's business ...

$\S 2$ [Socrates]: 'I think that, though you are in fact able, you shrink from taking charge' ...

$\$ 3$ 'In what deed', said Charmides, 'have you observed my ability?' ...

$\S 9$ [Socrates]: 'my good man, don't be ignorant of yourself' ...

Charmides has not gone into politics, although Socrates thinks he could. But Charmides lacks self-knowledge: although he has the ability, he does not know that he has it. This lack of self-knowledge prevents him from choosing the good. He is able to do something better than any of the options he knows he can do, namely, to succeed in politics. If he knew that he was capable of this, he would choose it, because he would recognize that option as better than the others. But he does not choose it, because he does not even consider it as an option. Since his deliberation can only usher in a choice to do one of the options he considers, his deliberation cannot result in choosing the good-or, perhaps more precisely, choosing the best. In short: it is because he does not know his own dunamis that he misrepresents his options, and it is because his deliberations are thus impoverished that he fails to do the fine and good-in this case, to go into politics.

There are other ways of misrepresenting one's options, of course, including representing something as an option for you which in fact is not-as is the case with Glaucon in Mem. 3.6. Glaucon thinks that he is capable of speaking in the assembly, though he in fact is not. In cases like Glaucon's, a failure to choose the good seems overdetermined. Glaucon fails to choose the best that he is capable of, not just because he does not choose the best among some set of options but also because he chooses something he is not capable of - something that is not really an option for him. Other factors will also overdetermine the failure of the unwise. For instance, they may represent their options correctly, but lack the ability to discriminate which options are fine and good. ${ }^{21}$ Or they may be incorrectly motivated: they may not even be trying to do the fine and good. Such discriminatory abilities and motivational factors certainly play a role in explaining why the wise are and the unwise are not able to do the fine and good, for Xenophon's Socrates as well as for Plato's. But the motivational factors play no role in explaining why the unwise are unable to do the fine and good even if they try, and so play no role in explaining why (praxis) is true, as the prohairetic account aims to do. The discriminatory abilities, by contrast, are so clearly relevant to explaining (praxis) that I here neglect them in order to focus on a part of the explanation of (praxis) which is specific to Xenophon's Socrates: the prohairetic account. Similarly, I neglect common ground between Plato's Socrates and Xenophon's on self-knowledge, for the sake of bringing out the interest of two commitments which are specific to Xenophon's Socrates, viz. (prohairesis) and (dunamis). For the same reason, I focus here on the negative story, about why the unwise lack that ability. That negative story will partly explain the positive claim that the wise have that ability, since it illuminates the obstacles which stand in the way of the unwise. It is possible that

${ }^{21}$ Socrates emphasizes this possibility in Mem. 4.1.5. 
Socrates thinks that, with those obstacles out of the way, the wise simply exercise general human abilities to make up their minds-abilities which they share with at least some of the unwise. But it is also possible, for all I say here, that Socrates had more to say about the prohairetic abilities of the wise-in Xenophon as well as in Plato. My aim here is to give not a complete explanation of the practical abilities that come with wisdom for Socrates, but a part of that explanation which is both philosophically rich and also specific to Xenophon's Socrates. So, in the rest of this section, I first adduce textual evidence for those two specifically Xenophontic commitments, (prohairesis) and (dunamis), and then respond to two serious worries one might have about the cogency of the prohairetic account.

Beyond the passages about Charmides and Glaucon in Mem. 3.6-7, there are two passages which support attributing (prohairesis) to Socrates, and two which support attributing (dunamis) to him. The first passage which supports (prohairesis) is the central text from the first section, Mem. 3.9.5. Socrates there says that knowers will not choose anything instead of the virtuous or fine and good. Since those knowers will also be wise, the wise will choose those things, too. Given the parallelism of the premises about knowledge and wisdom (that is, (iii) and (iv)) in that passage, it would be quite surprising if the wise and the unwise are supposed to be set apart by what they do but not by what they choose. Besides, if the unwise could choose the good, what would prevent them from doing it when they chose it and tried to do it?

A second passage which supports (prohairesis) comes in Mem. 4.5.11-12:

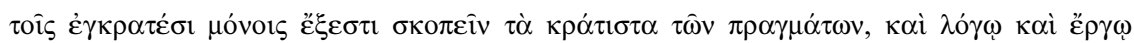

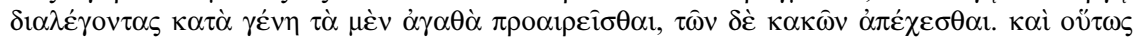

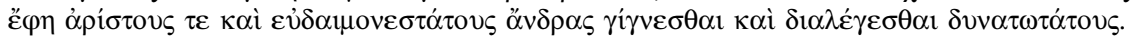

'for enkratics alone is it possible (a) to look into the most important of things, and (b) sorting them according to kind both (i) in word and (ii) in deed (c) to choose the good and abstain from the bad. And thus', he said, 'men come to be best and happiest and most dialectically capable.'

Although Socrates' praise here is officially of enkrateia, I argue below that it is underwritten by a claim about wisdom, viz. (prohairesis). For what he says about enkrateia, he thinks is made true by (prohairesis), in conjunction with the fact that wisdom requires enkrateia. To see this point, note first that Socrates does not say that all enkratics will be able to choose the good: he says that only enkratics will be able to. All enkratics will be able to choose the good only if all enkratics can do the right kind of sorting in word and deed. But Mem. 3.9.5 says that only the wise will be able to sort the most important things in deed, on the reasonable assumption that to sort those things in deed means: to do the fine and good. Moreover, it is quite plausible that sorting the most important things according to kind in words is something only the dialektikous are able to do. That is why Xenophon immediately after the quoted passage (in 4.6) goes on to show how Socrates brought his companions to be more dialektikos: because being dialektikos is an additional requirement, above and beyond enkrateia. The picture which naturally results is that, while all enkratics will be able to study the most important things, they still need to become dialektikos in order to sort them in word, and they then need to become wise in order to sort them in deed. If this picture is correct, then the praise of enkrateia hides a nested series of possibilities. All enkratics will be able to engage in (a); some of those who actually do engage in (a) will be able to engage in (b).(i); at least some of these will in turn will be able to engage in (b).(ii): and this last group will be wise. So only the wise will be able to engage in (c): to choose the good. 
There is another reason to think that wisdom is underwriting this praise of enkrateia.

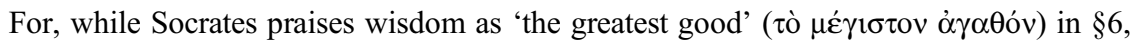
he has doubts about enkrateia which are marked in two ways in the chapter. First, Socrates' argument that enkrateia is the best thing for a human (in §8) is marked in both the conclusion and the premises as likely (zikós). Second, when Socrates at the start of 4.5 says that enkrateia is good for someone who means to do something fine, he is implicitly picking up on an earlier warning. In Mem. 4.3.1, Xenophon had written that Socrates

was not eager to make his companions eloquent or practical or inventive, but before these he thought sôphrosynê needed to come to be in them. For he considered that these things, without sôphrosynê, made them capable of greater injustice and more capable of doing wrong.

This earlier warning that being practical is morally ambiguous matters for the praise of enkrateia in Mem. 4.5 because that praise has two tasks. On the one hand, it is part of a protreptic for enkrateia. But it is also described as making those turned by this protreptic more practical. So Socrates should think that enkrateia is only good for those who have sôphrosyne..$^{22}$ I suggest that both the initial qualification about whom enkrateia is good for as well as the qualification of the argument as only likely are grounded in a certain amount of doubt about whether enkrateia requires sôphrosynê. In brief, Socrates is sure that all the wise can choose correctly, and that only enkratics are wise. But he is not sure that all enkratics can choose correctly. ${ }^{23}$ So it is (prohairesis) which underwrites the claim that only enkratics can choose the good.

Turn back now to (dunamis), the claim that the unwise lack knowledge of their own dunamis, and so lack self-knowledge. The clearest textual basis for both parts of this claim comes in Mem. 4.2:

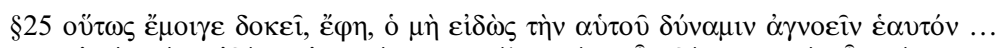

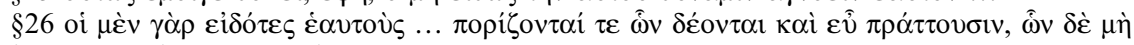

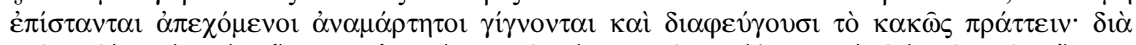

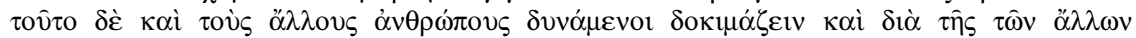

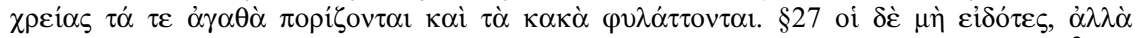

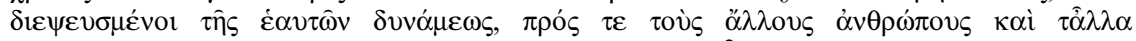

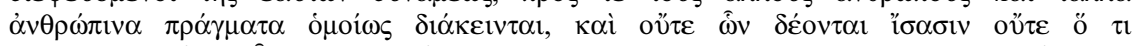

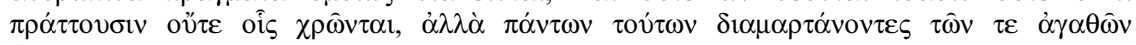
$\dot{\alpha} \pi \mathrm{o} \tau \gamma \chi \chi \alpha \dot{v o v \sigma l ~ . . . ~}$

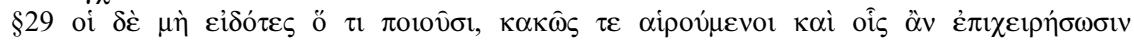
$\dot{\alpha} \pi \mathrm{o} \tau \nu \gamma \chi \alpha \dot{\alpha} v 0 v \tau \varepsilon \varsigma \ldots$

$\S 25$ 'Thus it seems right to me', [Euthydemus] said, 'that the one who doesn't know his own dunamis is ignorant of himself.' ...

$\$ 26$ [Socrates] 'Those who know themselves ... manage to do what they need to and do well, while, by avoiding doing what they do not know, they make no mistakes and avoid doing badly. For this reason, too, that they are able to judge others, through intercourse with others they manage to do the goods and they avoid the bads. $\$ 27$ Those who do not know, but are deceived

22 One might think that the Spartans are prime examples, for Xenophon, of enkratics who lack sôphrosynê: cf. N. Humble, 'Sophrosyne and the Spartans in Xenophon', in S. Hodkinson and A. Powell (edd.), Sparta: New Perspectives (Swansea, 2009), 339-54.

${ }^{23}$ This explanation, in terms of what Socrates is sure about, or has doubts about, is compatible with Socrates believing that enkrateia is the greatest good, wisdom and sôphrosynê, so that I am not here begging any disputed interpretative questions about what kind of relationship Socrates believes enkrateia bears to wisdom and sôphrosynê. 
about their own dunamis, are similarly disposed [that is, deceived] towards others and other human affairs. And neither do they know what they need nor what they do, nor whom they employ, but going wrong in everything they miss the goods ...

$\$ 29$ Those who don't know what they do, choosing badly and failing at what they attempt' ...

Earlier in $\S 25$, Socrates pushed Euthydemus to think about what self-knowledge is. Together, they hit upon the idea that self-knowledge is knowing one's own dunamis. The basic idea is simple. Someone with self-knowledge knows whether they are able to rule a city, be a general, run a marathon, judge the character of others, and so on. These abilities in turn require some knowledge of the world without-we have to know what it is to be a general, what a marathon is, what is required to rule a city. Socrates does not offer an exact theory of which abilities one must know about, in order to count as having self-knowledge. Nor is it clear that he is defining self-knowledge as knowledge of one's own abilities, as opposed to simply identifying a necessary condition for self-knowledge. ${ }^{24}$ But he does clearly connect self-knowledge to knowledge of one's own abilities and, through this knowledge, to action and to choice. Those with self-knowledge will do well and get the goods, those without self-knowledge will not, and will choose badly. It is difficult not to be struck by the parallels between self-knowledge here and wisdom in Mem. 3.9.5. Indeed, by the same heuristic employed in that passage, it would follow that self-knowledge is wisdom. In that case, what Socrates says here about self-knowledge also applies to wisdom.

That identification of wisdom and self-knowledge is also supported by the passage immediately after Mem. 3.9.5. In $\S \S 6-7$, Socrates says that madness is the opposite of wisdom, and implies that madness is ignorance of oneself:

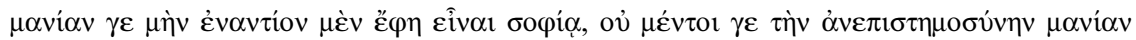

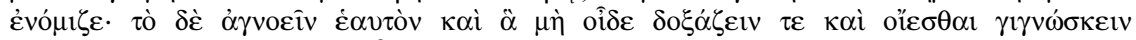

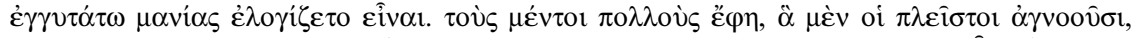

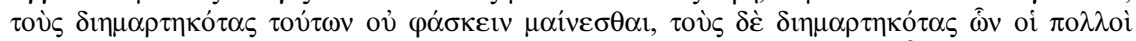

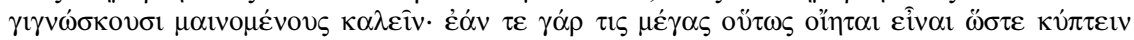

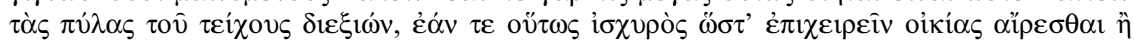

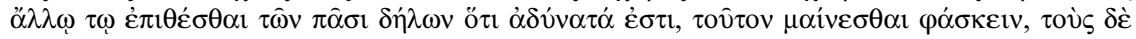

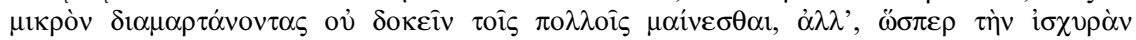

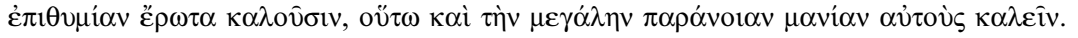

'Madness', he said, 'is the opposite of wisdom.' He did not, however, consider madness to be lack of knowledge. But to be ignorant of oneself and to believe and suppose oneself to know what one does not know, he reasoned to be nearest to madness. 'Yet the many', he said, 'do not say that those people are mad who go wrong about what most people are ignorant of, but call those mad who go wrong about what most people know. For if someone thinks himself so tall that he stoops as he goes out the city gates, or so strong that he chooses to try to pick up houses, or any other undertaking of those which it is obvious to all he is not capable of - this guy, they say, is mad. The many don't think that those who make small mistakes are mad, but just as they call strong desire love, so also they call great derangement madness.'

Socrates does not here assert that ignorance of oneself is madness. Instead, he first says that it is closest to madness, and then goes on to explain a way in which the many are mistaken about madness. These two things are, I suggest, not unrelated: Socrates refrains from identifying self-ignorance with madness for the reason that that claim would be easily misunderstood by those who mistakenly think that they know what

24 As C. Moore, Socrates and Self-Knowledge (Cambridge, 2015), 218 points out. 
madness is. The examples of supposed madness which follow make it clear that he is concerned with people who are ignorant of their own abilities (to walk under a tall gate, to pick up houses), and so lack self-knowledge. Socrates of course differs from the many on which mistakes are small mistakes, and so also on which abilities matter to self-ignorance. But the clear implication is that Socrates thinks that the same abilities matter for both madness and self-knowledge: it is not trivial things like knowing your height and physical strength that constitute self-knowledge, nor is it mistakes about them that constitutes madness. So this passage also supports the identification of self-knowledge and wisdom.

Despite the textual grounding which the prohairetic view thus enjoys, one might worry about its cogency. For it is not clear how to generalize from Charmides' and Glaucon's cases in order to make the prohairetic view plausible, particularly in the face of two worries. First, why think that correct choice is always required, in order to be able to do the fine and good? Do not many athletes just do the right actions without considering different options, as also Aristotle's phronimos does according to McDowell, among others? ${ }^{25}$ So why could not at least some of the fine and good be done without considering different options? Second, why think that self-ignorance in one area will prevent correct choice in other areas? For instance, why should Charmides' self-ignorance with respect to his political abilities affect his ability to do temperate things, or to be a good friend? Xenophon's Socrates does not squarely address these questions, so any replies to them will necessarily be speculative. With that caveat, I propose the following replies as most likely.

The first thing to note in response to the first of these worries is that (praxis) is not a claim about what is possibly true but a claim about an ability. It does not deny that the unwise can occasionally luck into doing something that happens to be fine and good. Rather, it says that the unwise lack an ability to do the fine and the good, so that it is only by luck that they occasionally manage to do them. Compare: a tennis player has an ability to aim the ball when they hit it. I do not, though I may get lucky. As Socrates puts the point in Mem. 3.9.14, good luck and praxis are 'entirely opposed'

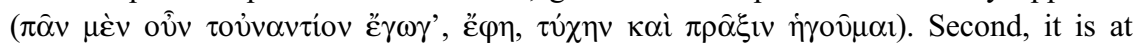
least plausible that the only way for humans to develop a general ability to do the fine and good is to cultivate their prohairetic abilities. If that is right, then McDowell's phronimos is able to act without prior deliberation only because they have a well-developed deliberative ability. Athletic skills often develop in a parallel way: one first has to engage in drills and reflection about how to do better, in order to develop into an athlete who can play skilfully. But once one can play skilfully, one may no longer need to reflect in order to do so. These two points underwrite a very plausible reply to the first worry, about how widespread choice is. The reply is in two ways concessive. It concedes that some fine and good actions can be done even by those who lack a general ability to do the fine and good, when they get lucky. And it concedes that the fully virtuous might often act without engaging in reflective deliberation about what to do. It emphasizes instead that this ability to act without reflection is dependent on a prohairetic ability which the unwise lack.

The second worry crops up in one form or another for all theses about the unity of the virtues, and there is no reason to think that Xenophon's Socrates would not have

25 J. McDowell, 'Some issues in Aristotle's moral psychology', in S. Everson (ed.), Companions to Ancient Thought 4: Ethics (Cambridge, 1998), 107-28. 
been able to give a response to it similar to the sophisticated responses articulated by defenders of Aristotle's version of the unity of the virtues. ${ }^{26}$ But a simpler response seems more likely. The unwise need not be like Charmides and Glaucon with respect to every choice situation, however closely specified. Some of the unwise may have abilities to choose correctly when it comes to carpentry, for instance, or making wings out of feathers and wax. But though the unwise may have an ability to choose-the-good-in-this-specific-choice-situation, they will be like Charmides and Glaucon with respect to the more general question: what should I do now? For all of one's abilities to benefit are relevant to that question. To make the thought vivid, imagine that you undergo a serious ethical re-evaluation of your life. Suppose, for instance, you become convinced of Peter Singer's contention that we should donate everything we have to charity, up to the point of marginal utility. ${ }^{27}$ What should you do now? That depends upon your abilities. If you could make a bigger difference later by purchasing luxury products now, then that is the way to go. But whether or not that is true is largely down to your abilities: how much you can do without partly determines where the point of marginal utility is. And your ability to contribute in the future is equally determinative. So, with respect to this more general question, it could be any of your abilities which is relevant: perhaps your skills as a friend will enable someone to go on to great things. ${ }^{28}$ In short, if you misrepresent your abilities to benefit in any way, you will misrepresent your options in ways that are very likely to be significant. Only by luck might you manage to consider as an option the best thing you are capable of.

Crucially, this failure is not simply a failure to discriminate the best among some set of options. Someone with knowledge of the good, but not themselves, might correctly discriminate. What is special to self-knowledge, and so to wisdom according to Xenophon's Socrates, is the authorship of your choices not in the sense of picking from a list but in the sense of authoring the right list. This is not a discriminative ability but an imaginative ability, to imagine what is possible for you. It is not simply an ability to answer questions about what to do but an ability to ask the right ones-for instance, by including the right options in questions like 'should I do this or should I instead do that?'

These replies to the worries about the cogency of the prohairetic view are speculative but philosophically rich. Perhaps they are so much so that readers will think them beyond the philosophical reach of Xenophon's Socrates. But the elements of the prohairetic account itself and the careful and unusually well-articulated argumentation of Mem. 3.9.5 are not speculative, and show Xenophon's Socrates to be capable of giving subtle and probing arguments for paradoxical theses. It thus seems reasonable to suppose that these speculative replies are not beyond the reach of Xenophon's Socrates, for he is a significant philosopher in his own right. That is a result about which I am happy to agree with Dorion and Morrison, even if the texts favour a unified view of wisdom, as partly constituted by a special prohairetic ability, over the splintered view of wisdom.

Humboldt Universität zu Berlin, Institut für Philosophie

JOSEPH BJELDE joseph.bjelde@hu-berlin.de

${ }^{26}$ E.g. D.C. Russell, 'Phronesis and the virtues: Nicomachean Ethics VI.12-13', in R. Polansky (ed.), The Cambridge Companion to Aristotle's Nicomachean Ethics (Cambridge, 2014), 203-20.

${ }_{27}$ P. Singer, 'Famine, affluence, and morality', Philosophy \& Public Affairs 1 (1972), 229-43; reprinted in id., Famine, Affluence, and Morality (Oxford and New York, 2016).

${ }^{28}$ The point is dramatized by consequentialism, but one need not be a consequentialist to think that any of your abilities to benefit is potentially relevant to what you should do. 